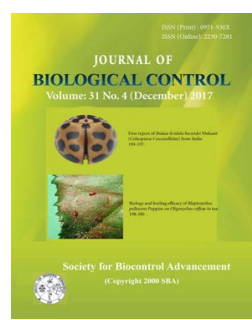

\title{
Aenasius arizonensis girault (Hymenoptera: Encyrtidae): A potential biocontrol agent of cotton Mealybug, Phenacoccus solenopsis Tinsley
}

\author{
S. THANGAVEL ${ }^{1 *}$ and N. GANAPATHY ${ }^{2}$ \\ ${ }^{1}$ Department of Agricultural Entomology, B A College of Agriculture, Anand Agricultural University, Anand - 388 110, Gujarat, India \\ ${ }^{2}$ Department of Entomology, Controllerate of Examinations, Tamil Nadu Agricultural University, Coimbatore - 641003, Tamil Nadu, \\ India \\ ${ }^{*}$ Corresponding author E-mail: entothanga@gmail.com
}

\begin{abstract}
The parasitization potential of three parasitoids viz., a parasitoid, Aenasius arizonensis, and two predators, Cheilomenes sexmaculata and Cryptolaemus montrouzieri. was studied on Phenococcus solenopsis under laboratory conditions. Among them A. arizonensis alone recorded parasitization to an extent of $40.91 \%$.
\end{abstract}

KEY WORDS: Aenasius Arizonensis, Mass Culturing, Phenococcus solenopsis, Parasitization

(Article chronicle: Received: 14.06.2017; Revised: 22.09.2017; Accepted: 10.12.2017)

\section{INTRODUCTION}

Cotton (Gossypium hirsutum L.), the "King of Fiber" popularly known as "White Gold", is an important cash crop in India. About 200 insect pests are reported to attack cotton crop in India (Anonymous, 1992). Among them, Phenococcus solenopsis Tinsley is a destructive pest of cotton, which originated from USA and co-evolved with numerous food plants. The devastating outbreak of $P$. solenopsis is reported to have caused nearly $30-60 \%$ yield losses from India and Pakistan during 2005-2009. Since then the pest has received worldwide attention as an invasive species of quarantine importance. Aenasius arizonensis (Girault) (= Aenasius bambawalei Hayat) (Hymenoptera: Encyrtidae), a solitary endoparasitoid has been recorded as an effective natural enemy of $P$. solenopsis.

An experimental trial with cotton (MCU 5) was conducted by sowing in the month of August 2016 in an area of 70 cents. Observations on mealybug and its natural enemies were recorded on weekly interval from September to November. The crop was kept free from pesticide application. Number of mealybug and its natural enemies per plant were recorded from five randomly selected plants. Ladybird bee- tles were recorded in situ. In the case of $A$. arizonensis, the mealybug samples on which adults of the parasitoids were observed in field were brought to lab and maintained for adult emergence. From this A. arizonensis parasitoids were enumerated. The data obtained were subjected to Regression and Correlation analysis. The significance of differences was tested by adopting F-tests, while the significance of difference between the treatment mean values was compared by LSD at 5 per cent probability (Gomes and Gomes, 1984).

In the present study, three natural enemies were recorded viz., a parasitoid, Aenasius arizonensis, and two predators, Cheilomenes sexmaculata and Cryptolaemus montrouzieri. The parasitization potential of parasitoids was studied on $P$. solenopsis under laboratory conditions. Among them A. arizonensis alone recorded parasitization to an extent of $40.91 \%$ (Table 1). Results from the regression $\left(\mathrm{R}^{2}=0.94\right)$ indicated that there was strong significant positive correlation of parasitoids and coccinellid predators with mealybug population. The findings of present study were in accordance with Aga et al., (2016) who reported maximum percentage $(90 \%)$ of parasitization in adult stage of mealybug. The results of the 
Table 1. Monitoring of mealybug and its natural enemies population in cotton ecosystem during 2016

\begin{tabular}{|c|c|c|c|c|c|c|}
\hline \multirow[t]{2}{*}{ Months } & \multirow[t]{2}{*}{ Weeks } & \multicolumn{5}{|c|}{ Mean number/ plant } \\
\hline & & Mealybug & Aenasius sp. & Cheilomenes sp. & Cryptolaemus sp. & $\begin{array}{l}\text { Total per cent para- } \\
\text { sitization }\end{array}$ \\
\hline September & I & 7.00 & 2.20 & 3.00 & 2.80 & 23.91 \\
\hline September & II & 12.40 & 7.00 & 5.60 & 1.20 & 36.08 \\
\hline September & III & 16.80 & 5.60 & 4.40 & 3.40 & 25.00 \\
\hline September & IV & 14.20 & 8.00 & 2.60 & 2.00 & 36.04 \\
\hline October & $\mathrm{I}$ & 22.60 & 12.40 & 7.00 & 3.60 & 35.43 \\
\hline October & II & 8.80 & 3.60 & 6.80 & 1.20 & 29.03 \\
\hline October & III & 13.40 & 8.00 & 5.00 & 2.40 & 37.38 \\
\hline October & IV & 23.20 & 14.20 & 8.40 & 4.80 & 37.97 \\
\hline November & $\mathrm{I}$ & 15.60 & 10.80 & 6.80 & 3.20 & 40.91 \\
\hline November & II & 26.20 & 18.00 & 3.20 & 2.60 & 40.72 \\
\hline November & III & 18.80 & 11.20 & 4.00 & 5.00 & 37.33 \\
\hline November & IV & 41.00 & 23.00 & 11.60 & 3.60 & 35.94 \\
\hline
\end{tabular}

study was also in line with Pala Ram and Saini (2010) who reported that, the activity of Aenasius arizonensis on P. solenopsis increased with significant decrease in the pest population and the incidence was confined only to $18 \%$ of the fields and $1.6 \%$ of the plants.

\section{ACKNOWLEDGEMENT}

The authors were thankful to Department of Agricultural Entomology, TNAU for providing facility for conducting research and Dr. S. Sridharan, Professor (Agricultural Entomology), TNAU, Coimbatore for the identification of parasitoids.

\section{REFERENCES}

Aga TM, Tambe VJ, Nagrare VS, and Bhausaheb Naikwadi. 2016. Parasitoid, Aenasius arizonensis (Girault)
(Hymenoptera: Encyrtidae): it's Biology, morphometrics, host stage preference and use in biological control. J Biol Control 30(2): 91-98.

Anonymous 1992. Agricultural Situation in India. May 1994. pp 110.

Gomez KA and Gomez AA. 1984. Statistical procedures for Agricultural Research. Second Edition. Wiley. 704pp.

Pala Ram and Saini RK. 2010. Biological control of Solenopsis mealybug, Phenacoccus solenopsis Tinsley on Cotton: A Typical Example of fortuitous Biological Control. J Biol Control 24(2). 